\title{
Localization of Superoxide Dismutases and Hydrogen Peroxide in Legume Root Nodules
}

\author{
Maria C. Rubio, ${ }^{1}$ Euan K. James, ${ }^{2}$ Maria R. Clemente, ${ }^{1}$ Bruna Bucciarelli, ${ }^{3}$ Maria Fedorova, ${ }^{3}$ \\ Carroll P. Vance, ${ }^{3}$ and Manuel Becana ${ }^{1}$ \\ ${ }^{1}$ Departamento de Nutrición Vegetal, Estación Experimental de Aula Dei, Consejo Superior de Investigaciones Científicas, \\ Apdo 202, 50080 Zaragoza, Spain; ${ }^{2}$ Centre for High Resolution Imaging and Processing, MSI/WTB Complex, School of Life \\ Sciences, University of Dundee, Dundee DD1 5EH, U.K.; ${ }^{3}$ Department of Agronomy and Plant Genetics, University of \\ Minnesota, 411 Borlaug Hall, 1991 Upper Buford Circle, St Paul, Minnesota 55108, U.S.A.
}

Submitted 9 April 2004. Accepted 2 July 2004.

Superoxide dismutases (SODs) catalyze the dismutation of superoxide radicals to $\mathrm{O}_{2}$ and $\mathrm{H}_{2} \mathrm{O}_{2}$ and thus represent a primary line of antioxidant defense in all aerobic organisms. $\mathrm{H}_{2} \mathrm{O}_{2}$ is a signal molecule involved in the plant's response to pathogen attack and other stress conditions as well as in nodulation. In this work, we have tested the hypothesis that SODs are a source of $\mathrm{H}_{2} \mathrm{O}_{2}$ in indeterminate alfalfa (Medicago sativa) and pea (Pisum sativum) nodules. The transcripts and proteins of the major SODs of nodules were localized by in situ RNA hybridization and immunogold electron microscopy, respectively, whereas $\mathrm{H}_{2} \mathrm{O}_{2}$ was localized cytochemically by electron microscopy of cerium-perfused nodule tissue. The transcript and protein of cytosolic CuZnSOD are most abundant in the meristem (I) and invasion (II) zones, interzone II-III, and distal part of the $\mathrm{N}_{2}$-fixing zone (III), and those of MnSOD in zone III, especially in the infected cells. At the subcellular level, CuZnSOD was found in the infection threads, cytosol adjacent to cell walls, and apoplast, whereas MnSOD was in the bacteroids, bacteria within infection threads, and mitochondria. The distinct expression pattern of CuZnSOD and MnSOD suggests specific roles of the enzymes in nodules. Large amounts of $\mathrm{H}_{2} \mathrm{O}_{2}$ were found at the same three nodule sites as CuZnSOD but not in association with MnSOD. This colocalization led us to postulate that cytosolic CuZnSOD is a source of $\mathrm{H}_{2} \mathrm{O}_{2}$ in nodules. Furthermore, the absence or large reduction of $\mathrm{H}_{2} \mathrm{O}_{2}$ in nodule tissue preincubated with enzyme inhibitors (cyanide, azide, diphenyleneiodonium, diethyldithiocarbamate) provides strong support to the hypothesis that at least some of the $\mathrm{H}_{2} \mathrm{O}_{2}$ originates by the sequential operation of an NADPH oxidase-like enzyme and CuZnSOD. Results also show that there is abundant $\mathrm{H}_{2} \mathrm{O}_{2}$ associated with degrading bacteroids in the senescent zone (IV), which reflects the oxidative stress ensued during nodule senescence.

In legume nodules, the superoxide radicals are generated in redox processes such as the respiration in the mitochondria and bacteroids, the autoxidation of leghemoglobin in the cytosol, and the direct reduction of $\mathrm{O}_{2}$ by nitrogenase, hydrogenase, and ferredoxin in the bacteroids (Dalton 1995). To avoid the poten-

Corresponding author: M. Becana; E-mail: becana@eead.csic.es

Dedicated to the memory of Professor Robert Klucas, our colleague and friend. tial toxic effects of superoxide radicals, nodules contain high levels of superoxide dismutases (SODs). These enzymes catalyze the dismutation of the superoxide radicals and thus represent a primary line of protection against oxidative damage. The information on the distribution of SODs in nodules is, however, scant and based mainly on assays of SOD activity in purified organelles (Becana et al. 1989; Puppo et al. 1987). Although useful, these studies should be complemented with detailed microscopic analysis to localize the SODs and thus gain important information on their protective and regulatory roles in nodules.

An important and frequently overlooked feature of SODs is that they may produce significant amounts of $\mathrm{H}_{2} \mathrm{O}_{2}$ at physiological $\mathrm{pH}$ (Fridovich 1989). While excess $\mathrm{H}_{2} \mathrm{O}_{2}$ is potentially harmful, the maintenance of a low steady-state concentration of $\mathrm{H}_{2} \mathrm{O}_{2}$ in plants is critical because it is a signal molecule that modulates gene expression in response to pathogen attack and other stress situations (Lamb and Dixon 1997; Levine et al. 1994). For example, transient and local accumulations of $\mathrm{H}_{2} \mathrm{O}_{2}$ are implicated in the hypersensitive response and programmed cell death, albeit at different threshold levels (Grant and Loake 2000; Levine et al. 1994). Furthermore, $\mathrm{H}_{2} \mathrm{O}_{2}$ and probably other peroxides are involved in nodule formation (Santos et al. 2001) and senescence (Alesandrini et al. 2003; Escuredo et al. 1996; Evans et al. 1999), perhaps by also operating at different concentrations and subcellular targets.

In this work, we examine the hypothesis that SODs are a source of $\mathrm{H}_{2} \mathrm{O}_{2}$ by localizing the two most abundant SODs, as well as their product, in nodules. Distinct patterns of tissue and cell expression (transcripts and proteins) for cytosolic $\mathrm{CuZn}$ SOD and mitochondrial MnSOD point out specific roles for the two enzymes. Colocalization of $\mathrm{CuZnSOD}$ and $\mathrm{H}_{2} \mathrm{O}_{2}$ in the cytosol adjacent to cell walls, in the infection threads, and in the apoplast leads us to postulate that $\mathrm{CuZnSOD}$, but not MnSOD, is involved in producing $\mathrm{H}_{2} \mathrm{O}_{2}$ in nodules. Inhibitor studies provide strong support to the hypothesis that, at least in infection threads, a neutrophil-like NADPH oxidase is the source of superoxide radicals that, in turn, are dismutated by $\mathrm{CuZnSOD}$ to $\mathrm{H}_{2} \mathrm{O}_{2}$. This may then be used for cell growth and cross-linking of proteins, which are required for successful nodulation.

\section{RESULTS}

SOD isozymes in alfalfa and pea nodules.

The first necessary step of this work was to assay SOD activities and identify SOD isozymes in alfalfa and pea nodules. Actively $\mathrm{N}_{2}$-fixing nodules were harvested from plants having the same phenological stage (late vegetative growth period). The 
nodule plant fraction was extracted with a SOD-optimized medium containing $0.1 \%$ Triton $\mathrm{X}-100$, a detergent concentration sufficient to break mitochondria, peroxisomes, and plastids but not the bacteroids (data not shown). The SOD activities (mean $\pm \mathrm{SE}, n=4$ ) were $1,004 \pm 46$ and $620 \pm 40$ units per gram of fresh weight for alfalfa and pea nodules, respectively, which are in the range reported previously (Escuredo et al. 1996; Rubio et al. 2002).

The SOD isozymes were identified using activity gels and immunoblots. The nodules of both legume species contained one MnSOD and two CuZnSOD isozymes. On the basis of previous studies of SODs in legumes (Corpas et al. 1991), the MnSOD can be assigned to the mitochondrial isozyme and the two CuZnSODs to the plastid and cytosol isozymes. Nodules also had one FeSOD isozyme, presumably in the plastids, but this was not investigated further. The calculated molecular mass (Ferguson's plots) were 32 to $34 \mathrm{kDa}$ for CuZnSOD and 80 to $83 \mathrm{kDa}$ for MnSOD. Polyclonal antibodies raised to spinach cytosolic $\mathrm{CuZnSOD}$ and to rice mitochondrial MnSOD were used for immunoblot analysis (Fig. 1). The CuZnSOD antibody recognized a single protein band of $21 \mathrm{kDa}$ in alfalfa and $19 \mathrm{kDa}$ in pea (Fig. 1A), whereas the MnSOD antibody recognized a protein band of approximately $25 \mathrm{kDa}$ for the two legumes (Fig. 1B). Taking into account the apparent molecular mass of the native proteins and of the corresponding subunits, we conclude that the CuZnSOD and MnSOD of the nodule plant fraction are homodimeric and homotetrameric proteins, respectively, as occurs with other plant SODs (Scandalios 1997).
The SOD isozymes of free-living rhizobia and their symbiotic forms were also analyzed in sodium dodecyl sulfate (SDS) gels (Fig. 1C and D). Bacteroids were highly purified from alfalfa and pea nodules using Percoll gradients to avoid contamination with mitochondria, peroxisomes, and plastids that may also contain SOD. The absence of contamination of bacteroids with nodule plant material was confirmed by the distinct electrophoretic mobility of bacteroidal MnSOD (dimer) and mitochondrial MnSOD (tetramer) on native SOD-activity gels (data not shown). Blots probed with the MnSOD antibody showed a major immunoreactive band of $25 \mathrm{kDa}$ for the rhizobia (Fig. 1C) and bacteroids (Fig. 1D).

\section{Localization of SOD transcripts in nodules.}

The localizations of transcripts encoding cytosolic CuZnSOD and mitochondrial MnSOD were investigated using ${ }^{35} \mathrm{~S}$-UTPlabeled RNA probes transcribed in the sense or antisense orientations. The probes were hybridized to longitudinal sections of paraffin-embedded alfalfa and pea nodule tissue (Fig. 2). For the structural description of nodules, the nomenclature of Vasse and associates (1990) was followed: meristem (zone I), invasion zone (zone II), interzone II-III, $\mathrm{N}_{2}$-fixing or infected zone (zone III), and senescent zone (zone IV). Hybridization specific to the radiolabeled probe is seen as white silver grains when tissue is viewed under dark field optics. The CuZnSOD transcript was found to be highly expressed in the apical region of alfalfa and pea nodules, particularly in zones I and II,and in the interzone II-III (Fig. 2A through D, I, and J). Signal was also detected in

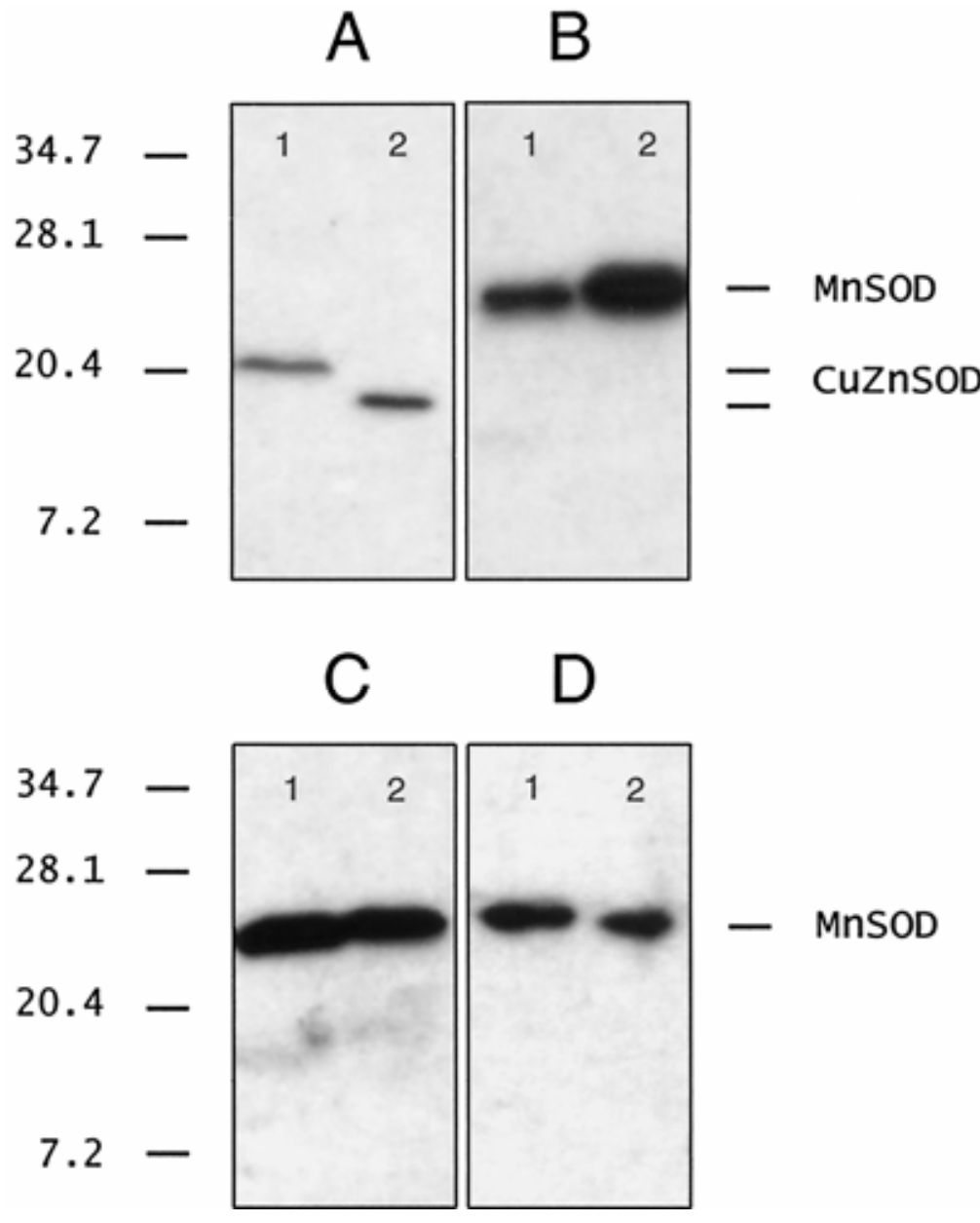

Fig. 1. Immunoblot analysis of superoxide dismutases (SODs). A, Cytosolic CuZnSOD and B, MnSOD from the plant fraction of alfalfa (1) and pea (2) nodules. MnSOD from C, free-living rhizobia and D, bacteroids of alfalfa (1) and pea (2) nodules. No immunoreactive bands were detected with the CuZnSOD antibody in the bacteroids. Protein loaded per lane was $15 \mu \mathrm{g}$ (A and B) or $5 \mu \mathrm{g}(\mathrm{C}$ and D). Molecular mass (kDa) markers are indicated on the left. 

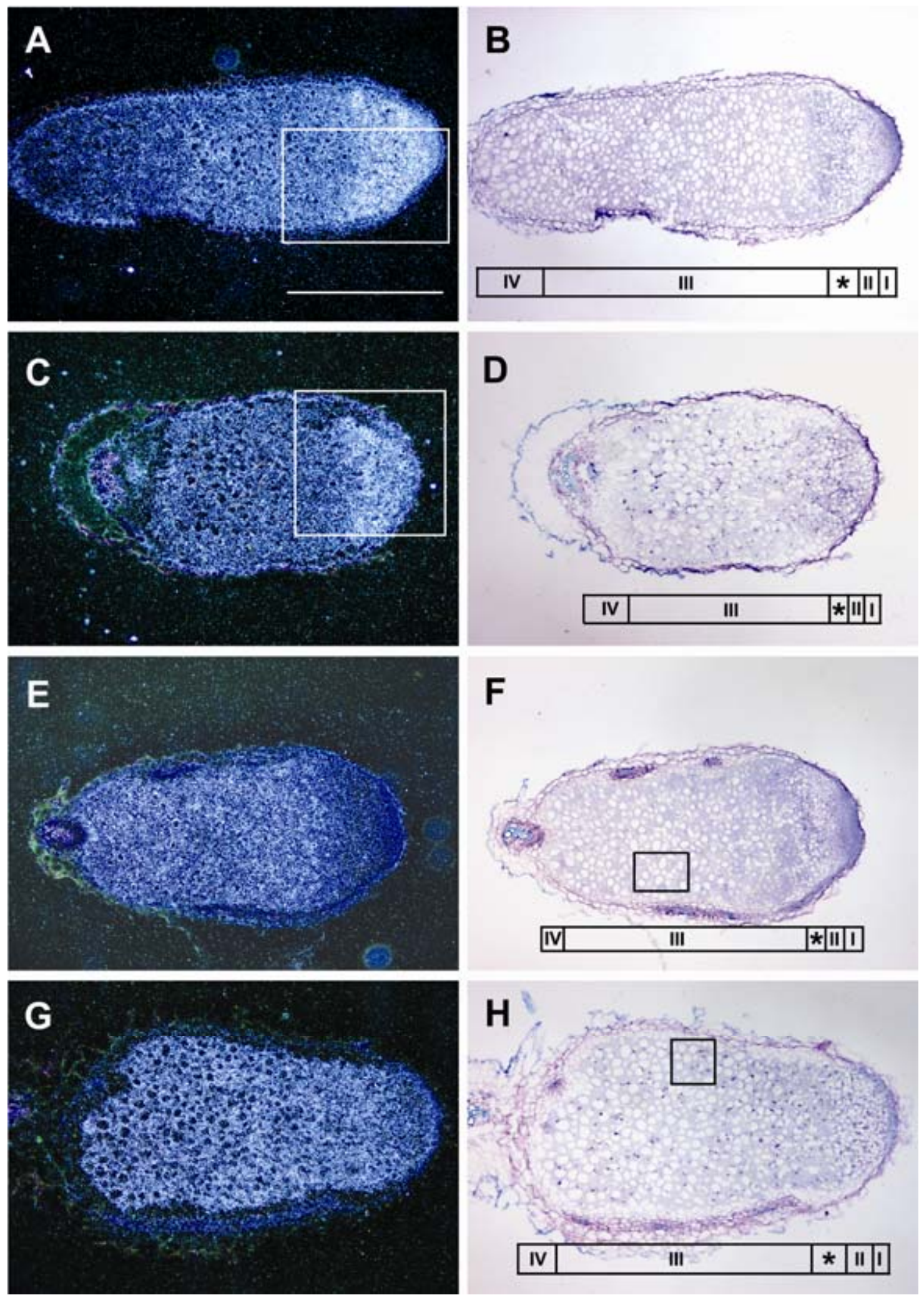

Fig. 2. In situ localization of cytosolic CuZnSOD and mitochondrial MnSOD transcripts in alfalfa (7-week-old) and pea (3-week-old) nodules. A through L, Images represent longitudinal sections through alfalfa (A, B, E, F, I, and K) and pea (C, D, G, H, J, and L) nodules. Bright-field images B, D, F, and H correspond to dark-field images A, C, E, and G, respectively. A 10x magnification of the boxed region in A and $\mathrm{C}$ is shown in I and J, and a 40x magnification of the boxed region in $\mathrm{F}$ and $\mathrm{H}$ is shown in $\mathrm{K}$ and $\mathrm{L}$, respectively. All other images represent a $4 \times$ magnification. The signal reflecting transcript localization in the dark-field images is seen as white silver grains. In the $40 \times$ bright-field images $(\mathrm{K}$ and $\mathrm{L})$, the silver grains appear black. Nodule structure was denoted according to Vasse and associates (1990): meristem (zone I), invasion zone (zone II), interzone (zone *), $\mathrm{N}_{2}$-fixing zone (zone III), and senescent zone (zone IV). Note enhanced signal intensity for CuZnSOD in zones I, II, and * (A, C, I, and J). By comparison, signal deposition for MnSOD is higher in zone III (E and G). Signal of MnSOD transcript for both alfalfa (K) and pea (L) nodules appears more abundant in infected cells (In) than in uninfected cells (Un). $\mathbf{M}$ and $\mathbf{N}$, For orientation and comparison, hybridization of an antisense leghemoglobin transcript in pea nodules shown. $\mathbf{O}$ and $\mathbf{P}$, Controls of alfalfa nodules with the sense probe show that the signal is specific for CuZnSOD since no signal is detected. This was also found to be the case for the sense control of the MnSOD probe (data not shown). Bars= $1 \mathrm{~mm}(\mathrm{~A}), 0.25 \mathrm{~mm}(\mathrm{I})$, and $0.1 \mathrm{~mm}(\mathrm{~K})$. 

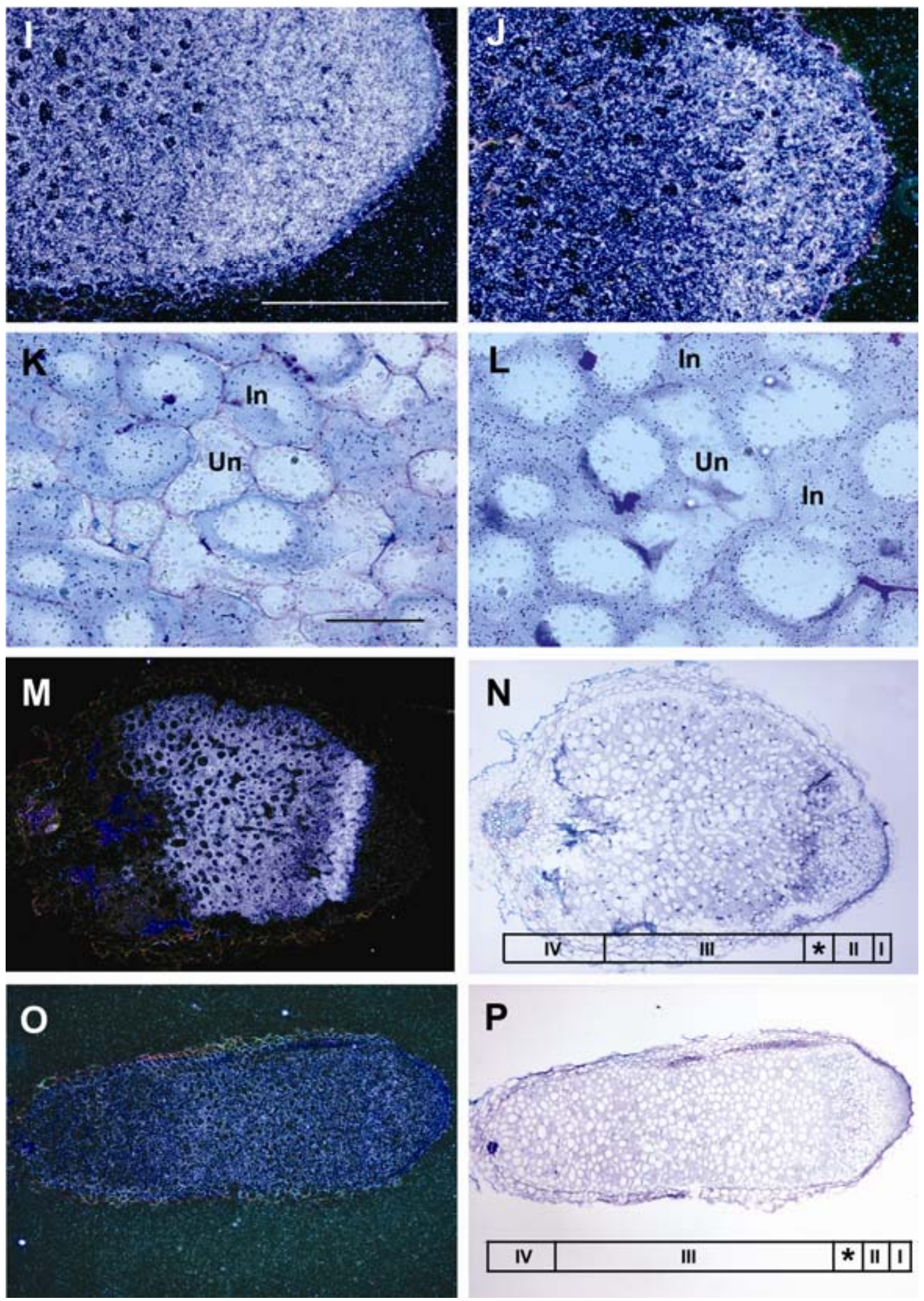

Fig. 2. Continued from previous page.

zone III, albeit at a lower intensity. Infected and uninfected cells showed no distinctive differences in hybridization signal intensity. In contrast, in both alfalfa and pea nodules, the MnSOD transcript was more highly expressed in zone III (Fig. 2E through $\mathrm{H}$ ), particularly in the infected cells (Fig. $2 \mathrm{~K}$ and L). The apical region of the nodule and the uninfected cells had low to no signal. There was no signal when CuZnSOD and MnSOD sense probes were hybridized to equivalent tissue sections (data not shown).

\section{Immunogold localization of SODs in nodules.}

The CuZnSOD and MnSOD proteins were localized in nodules by immunogold electron microscopy. Labeling of alfalfa and pea nodules with the cytosolic CuZnSOD anti- 
body showed that the protein localized predominantly in zones I and II, interzone II-III, and most distal part of zone III (Fig. 3). Dense labeling was found in the cytosol, particularly in 'pockets' next to cell walls of cells in zones I and II (Fig. 3A). There was also intense labeling associated with infection threads (Fig. 3B and C) and some weak labeling in vacuoles of cells in zones I and II. In alfalfa and pea nodules, labeling was also observed close to (and within) intercellular spaces in the cortex adjacent to zones I, II, and III, as well as in the cell walls adjacent to intercellular spaces of zone III itself (Fig. 3D). The same study was conducted with the MnSOD antibody. For both legume nodules, there was intense labeling of bacteria within infection threads (Fig. 4A and B) and of bacteroid membranes (Fig. 4D). As expected, there was also some labeling of mitochondria in infected cells (Fig. 4C).

Another polyclonal antibody, raised against spinach plastid

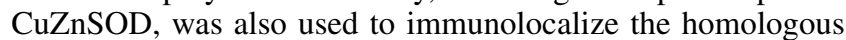
isozyme in alfalfa and pea nodules and to check the cross-reactivity of the antibodies with the two CuZnSODs. Labeling of plastid CuZnSOD was weak, especially in alfalfa, and was found to be associated with amyloplasts (data not shown). There was neither labeling of the cytosolic CuZnSOD in the amyloplasts nor of the plastid CuZnSOD in the cytosol, indicating that both antibodies are rather specific for the corresponding isozymes.

\section{Cytochemical localization \\ of $\mathrm{H}_{2} \mathrm{O}_{2}$ in nodules and inhibitor studies.}

The presence of $\mathrm{H}_{2} \mathrm{O}_{2}$ in nodules was evidenced by electron microscopy with a technique based on the deposition of electron dense cerium perhydroxides formed by the reaction of cerium ions with $\mathrm{H}_{2} \mathrm{O}_{2}$ (Bestwick et al. 1997). In both alfalfa and pea nodules, $\mathrm{H}_{2} \mathrm{O}_{2}$ was observed in infection threads in zones II and III. Specifically, it was found surrounding bacteria within the infection threads, in the thread walls, and in 'patches' in the thread matrices (Fig. 5A, B, and D). In general, infection threads in zone III tended not to be so densely stained as those in zone II (data not shown). In addition to the infection threads, $\mathrm{H}_{2} \mathrm{O}_{2}$ was clearly seen in cell walls and in intercellular spaces of the cortex adjacent to zones I and II (Fig. 5C). There was also abundant $\mathrm{H}_{2} \mathrm{O}_{2}$ surrounding disintegrating bacteroids in zone IV (Fig. 5E). Infection threads from control nodules that had not been perfused with cerium showed no electrondense precipitates (Fig. 5F).

The same technique was used to gain information on the source of $\mathrm{H}_{2} \mathrm{O}_{2}$ in nodules. These were detached from roots, were rapidly cut into pieces, and were incubated in buffer alone or in buffer supplemented with enzyme inhibitors or catalase prior to cerium perfusion. Control nodules infiltrated directly with cerium solution showed $\mathrm{H}_{2} \mathrm{O}_{2}$ staining similar to that in the samples preincubated in buffer (Fig. 6A), indicating that there was not artifactual formation of $\mathrm{H}_{2} \mathrm{O}_{2}$ during the preincubation period. Nodule samples treated with cyanide (inhibitor of cytosolic CuZnSOD and peroxidases) or azide (inhibitor of peroxidases) showed no detectable $\mathrm{H}_{2} \mathrm{O}_{2}$ in the infection threads, cell walls, and apoplast (Fig. 6B). Treatment with diphenyleneiodonium (DPI) (inhibitor of NADPH oxidase) or diethyldithiocarbamate (DDC) (inhibitor of CuZnSOD) also caused the virtual disappearance of $\mathrm{H}_{2} \mathrm{O}_{2}$ in infection threads and largely decreased $\mathrm{H}_{2} \mathrm{O}_{2}$ staining in the cell walls and apoplast (Fig. 6C through E). An additional control was included by treating nodule samples with catalase. This completely prevented $\mathrm{H}_{2} \mathrm{O}_{2}$ staining in infected threads, cell walls, and apoplast, proving that $\mathrm{H}_{2} \mathrm{O}_{2}$ was the reactive oxygen species being specifically detected by the cerium technique (Fig. 6F).

\section{DISCUSSION}

In this work, the hypothesis that SODs are a source of $\mathrm{H}_{2} \mathrm{O}_{2}$ in nodules was examined by combining localization and inhibitor studies. A first novel result is the differential expression of the cytosolic CuZnSOD $(\operatorname{sod} C c)$ and mitochondrial MnSOD $(\operatorname{sodA})$ genes in nodule tissues. The CuZnSOD transcript and protein are predominantly localized in the nodule apex, which may reflect activation of the $\operatorname{sod} C \mathrm{c}$ promoter in the meristem and invasion zone. Transcription of sodCc could be activated by thiols such as cysteine and glutathione (Hérouart et al. 1993), which are abundant in the apex of indeterminate nodules (Matamoros et al. 1999) or by the superoxide radicals produced in the infection threads (Santos et al. 2001) or both. In contrast, the MnSOD protein and its gene-specific transcript are very abundant in zone III, particularly in the infected cells, which strongly suggests a protective role of MnSOD in the symbiotic interaction.

A second finding in this work is the colocalization of $\mathrm{CuZnSOD}$ and $\mathrm{H}_{2} \mathrm{O}_{2}$ in the cytosol adjacent to cell walls in zone I, in the walls and matrices of infection threads in zone II, and in the intercellular spaces in the cortex adjacent to zones I and II. Interestingly, $\mathrm{H}_{2} \mathrm{O}_{2}$ was not detected in association with MnSOD or in two subcellular compartments, the cytosol and peroxisomes, known to generate reactive oxygen. In the latter case, the lack of staining is not due to the inability of cerium ions to enter the cells, because optimal conditions for $\mathrm{H}_{2} \mathrm{O}_{2}$ staining in plant cells and organelles were used (Bestwick et al. 1997; Blokhina et al. 2001) and because inhibitors and catalase, which are relatively large molecules, reached their targets even after shorter incubations. Rather, the absence of $\mathrm{H}_{2} \mathrm{O}_{2}$ in the cytosol and peroxisomes may be attributed to its rapid scavenging by ascorbate peroxidase and catalase, respectively, which are very abundant in nodules (Dalton 1995). This would agree with the suggestion that cerium primarily reacts with the excess of $\mathrm{H}_{2} \mathrm{O}_{2}$ that is not being rapidly metabolized (Bestwick et al. 1997).

The rapid generation of reactive oxygen species ('oxidative burst') is an early feature of the hypersensitive response in the plant-pathogen interaction (Lamb and Dixon 1997). However, the existence of a genuine oxidative burst during the symbiotic interaction is less clear (Shaw and Long 2003). Incompatible Nod factors elicit a defensive response of the plant, but compatible Nod factors suppress it (Bueno et al. 2001; MartínezAbarca et al. 1998). Similarly, compatible Nod factors fail to significantly enhance $\mathrm{H}_{2} \mathrm{O}_{2}$ efflux in the roots, suggesting that, at least during the initial interaction, there is no oxidative burst (Shaw and Long 2003). In contrast, other experiments show that rhizobia can elicit a hypersensitive reaction that is probably involved in the autoregulation of nodule number (Vasse et al. 1993) and that rhizobia and Nod factors trigger production of reactive oxygen (D'Haeze et al. 2003; Ramu et al. 2002; Santos et al. 2001). These apparently contradictory results may be reconciled by assuming that the production of reactive oxygen is modulated at different timepoints of the symbiotic interaction (Shaw and Long 2003). Our observation of intense $\mathrm{H}_{2} \mathrm{O}_{2}$ staining at the surface of bacteria within infection threads has not been reported previously and is consistent with a defensive but probably limited response of the plant to rhizobial invasion. However, other explanations, such as a metabolic production of $\mathrm{H}_{2} \mathrm{O}_{2}$ by the bacteria, cannot be excluded. We also found, as did others (D'Haeze et al. 2003; Santos et al. 2001), large amounts of $\mathrm{H}_{2} \mathrm{O}_{2}$ in the matrix and cell walls of infection threads. This $\mathrm{H}_{2} \mathrm{O}_{2}$ may be involved in the oxidative cross-linking of hydroxyproline- and tyrosine-rich glycoproteins, which is thought to be required for cell wall growth and progression of infection threads (Salzwedel and Dazzo 1993; Wisniewski et al. 2000). 


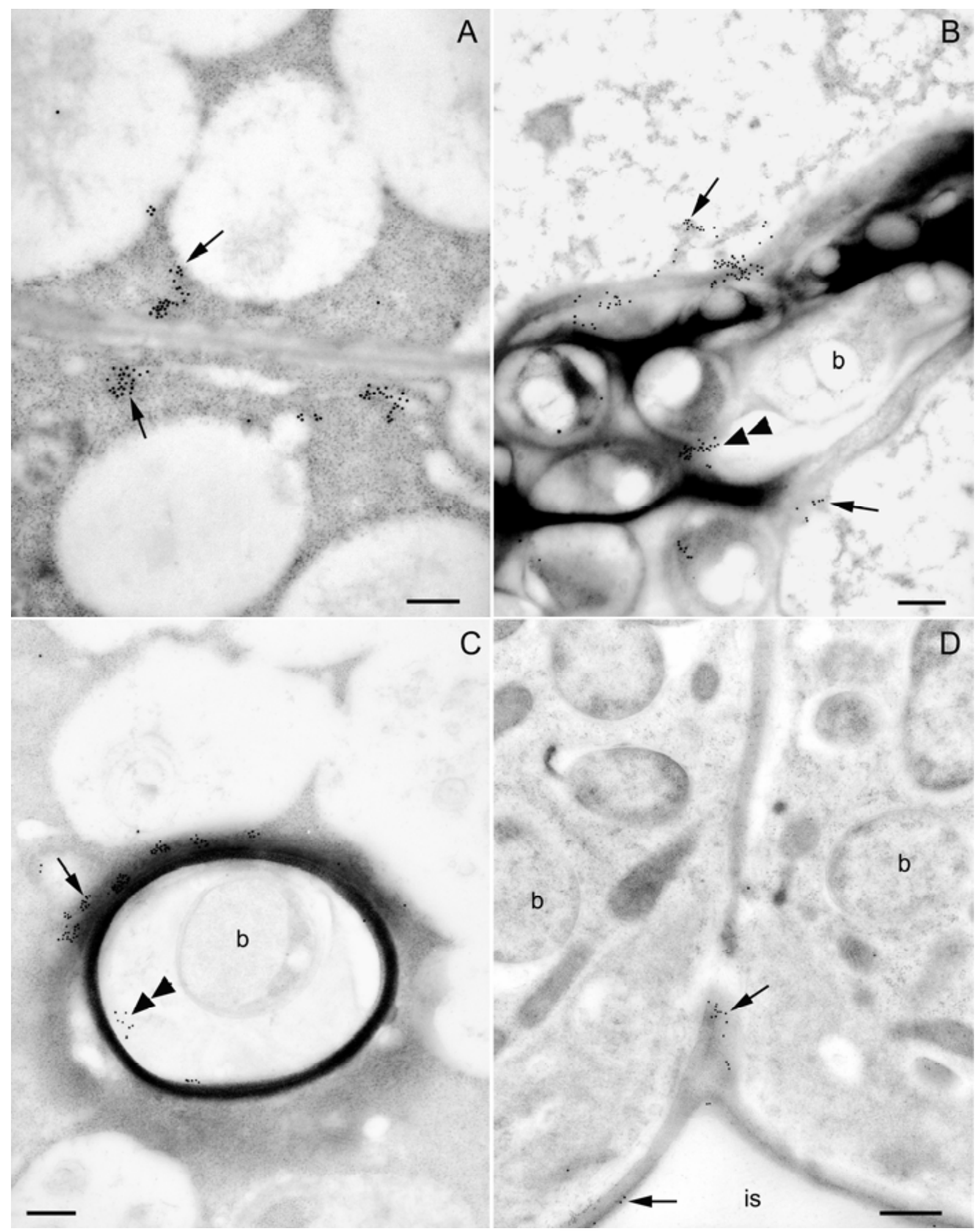

Fig. 3. Immunogold localization of CuZnSOD in $\mathbf{A}$ through $\mathbf{C}$, alfalfa and $\mathbf{D}$, pea nodules. A, Meristematic cells from zone I of nodules showing intense labeling of 'vesicles' (arrows) associated with the cell wall. B and C, Longitudinal and transverse sections, respectively, of infection threads from zone II, showing intense labeling of the cytoplasm (arrows) immediately adjacent to the thread wall. Also note that there is some labeling within the matrix of the thread (double arrowheads) but relatively little on the bacteria (b) in the thread. D, Infected cells in zone III. Note that there is labeling (arrows) within the cell walls adjacent to an intercellular space (is). $\mathrm{b}=$ bacteroids. Bars $=200 \mathrm{~nm}$ (A), $240 \mathrm{~nm}$ (B and C), and $500 \mathrm{~nm}$ (D). 
The main reactive oxygen species generated in the oxidative burst elicited by pathogens are the superoxide radicals and $\mathrm{H}_{2} \mathrm{O}_{2}$ (Lamb and Dixon 1997). Two major mechanisms have been proposed: generation of superoxide radicals by a neutro- phil-like NADPH oxidase in the plasma membrane and generation of $\mathrm{H}_{2} \mathrm{O}_{2}$ by a $\mathrm{pH}$-dependent peroxidase in the apoplast and cell walls (Desikan et al. 1996; Grant and Loake 2000; Lamb and Dixon 1997). Inhibitors are commonly used to dis-

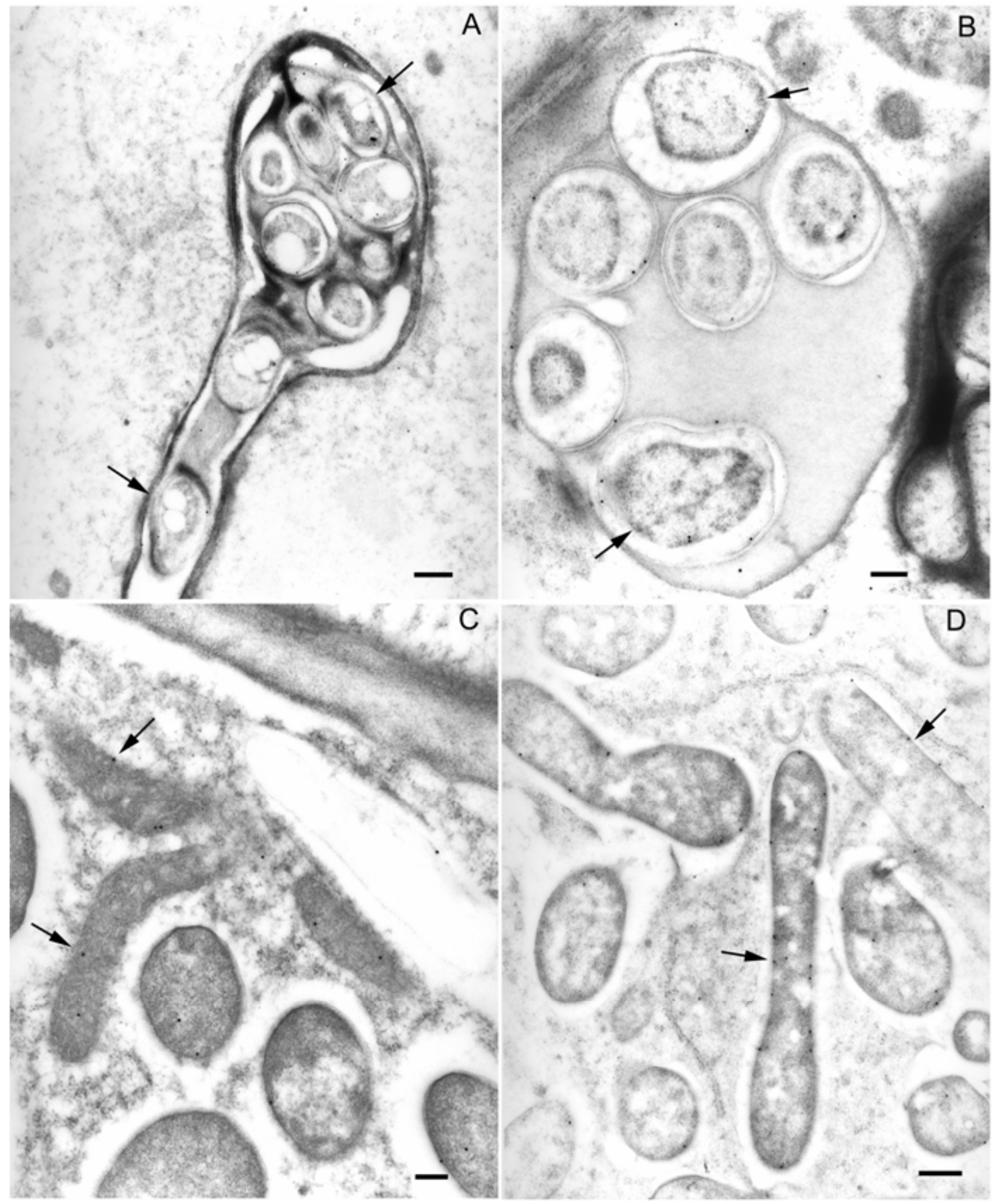

Fig. 4. Immunogold localization of MnSOD in $\mathbf{A}$ through $\mathbf{C}$, alfalfa and $\mathbf{D}$, pea nodules. A and $\mathbf{B}$, Newly-infected cells from zone II with infection threads and infection droplets, respectively, containing bacteria that express MnSOD (arrows). C and D, Infected cells in zone III showing, respectively, labeling of mitochondria (arrows in C) and bacteroids (arrows in D). Bars = $500 \mathrm{~nm}$ (A and D), $250 \mathrm{~nm}(\mathrm{~B})$, and $160 \mathrm{~nm}(\mathrm{C})$. 

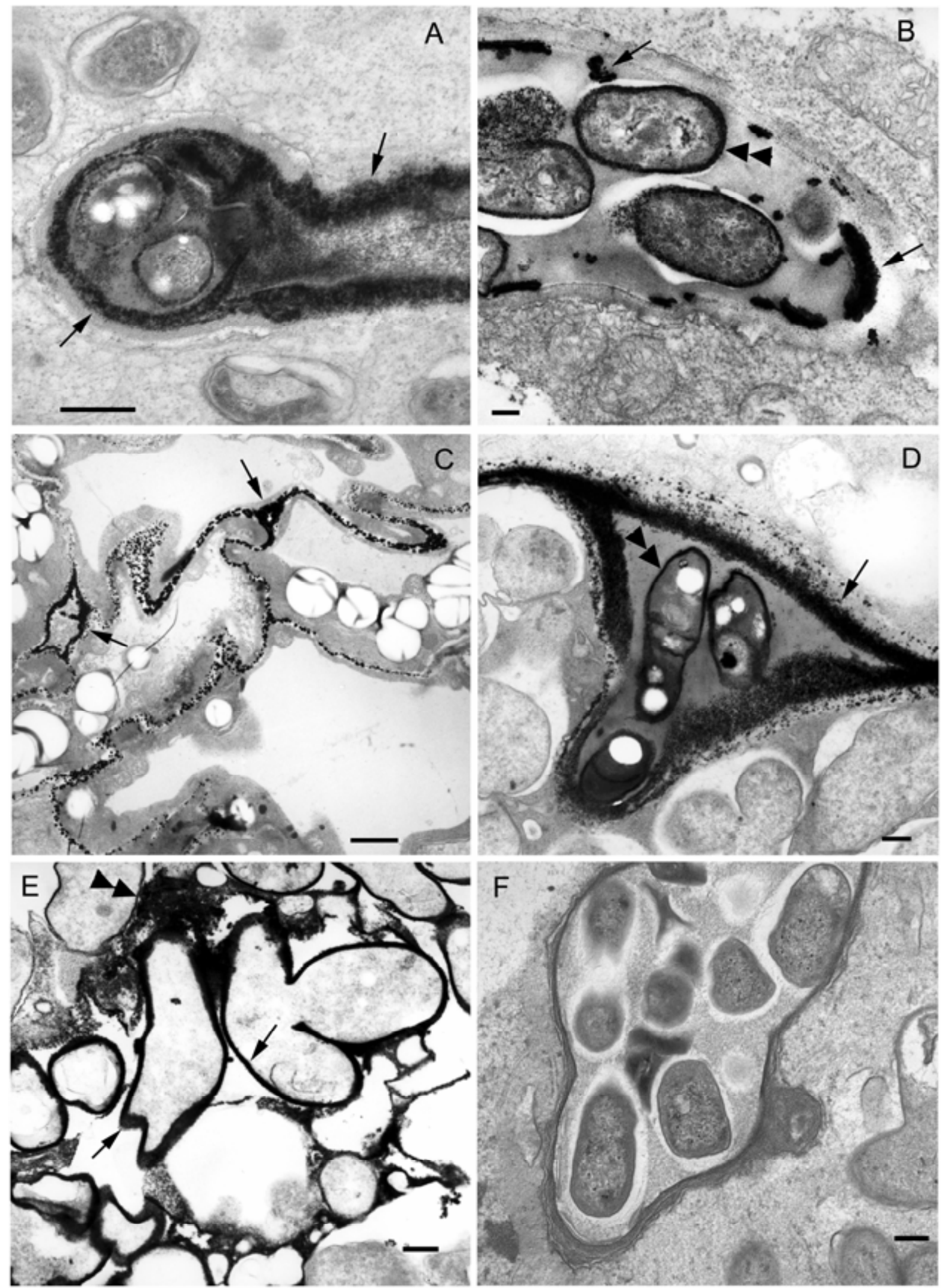

Fig. 5. Cytochemical staining of $\mathrm{H}_{2} \mathrm{O}_{2}$ in $\mathbf{A}$, alfalfa and $\mathbf{B}$ through $\mathbf{E}$, pea nodules. Fresh nodules were perfused with cerium before being processed conventionally for electron microscopy. The presence of $\mathrm{H}_{2} \mathrm{O}_{2}$ is marked by electron-dense precipitates of cerium perhydroxides. A through $\mathbf{D}$, Localization of $\mathrm{H}_{2} \mathrm{O}_{2}$ in the matrix and walls of infection threads in zone II (arrows in A and B) and in zone III (arrow in D). $\mathrm{H}_{2} \mathrm{O}_{2}$ is also abundant in the cell walls and intercellular spaces in the cortex adjacent to zone II (arrows in C). Note that $\mathrm{H}_{2} \mathrm{O}_{2}$ also surrounds the bacteria within the threads (double arrowheads in B and D). E, Senescing cell in zone IV containing bacteroids surrounded by $\mathrm{H}_{2} \mathrm{O}_{2}$ (arrow), which is also present in the degrading cytoplasm of the host cell (double arrowhead). F, Section of infection thread from zone II of pea nodules without addition of cerium. This is a negative control showing no electron-dense precipitates. Bars $=400 \mathrm{~nm}(\mathrm{~A}), 150 \mathrm{~nm}(\mathrm{~B}), 1 \mu \mathrm{m}(\mathrm{C})$, and $300 \mathrm{~nm}(\mathrm{D}$ through F). 

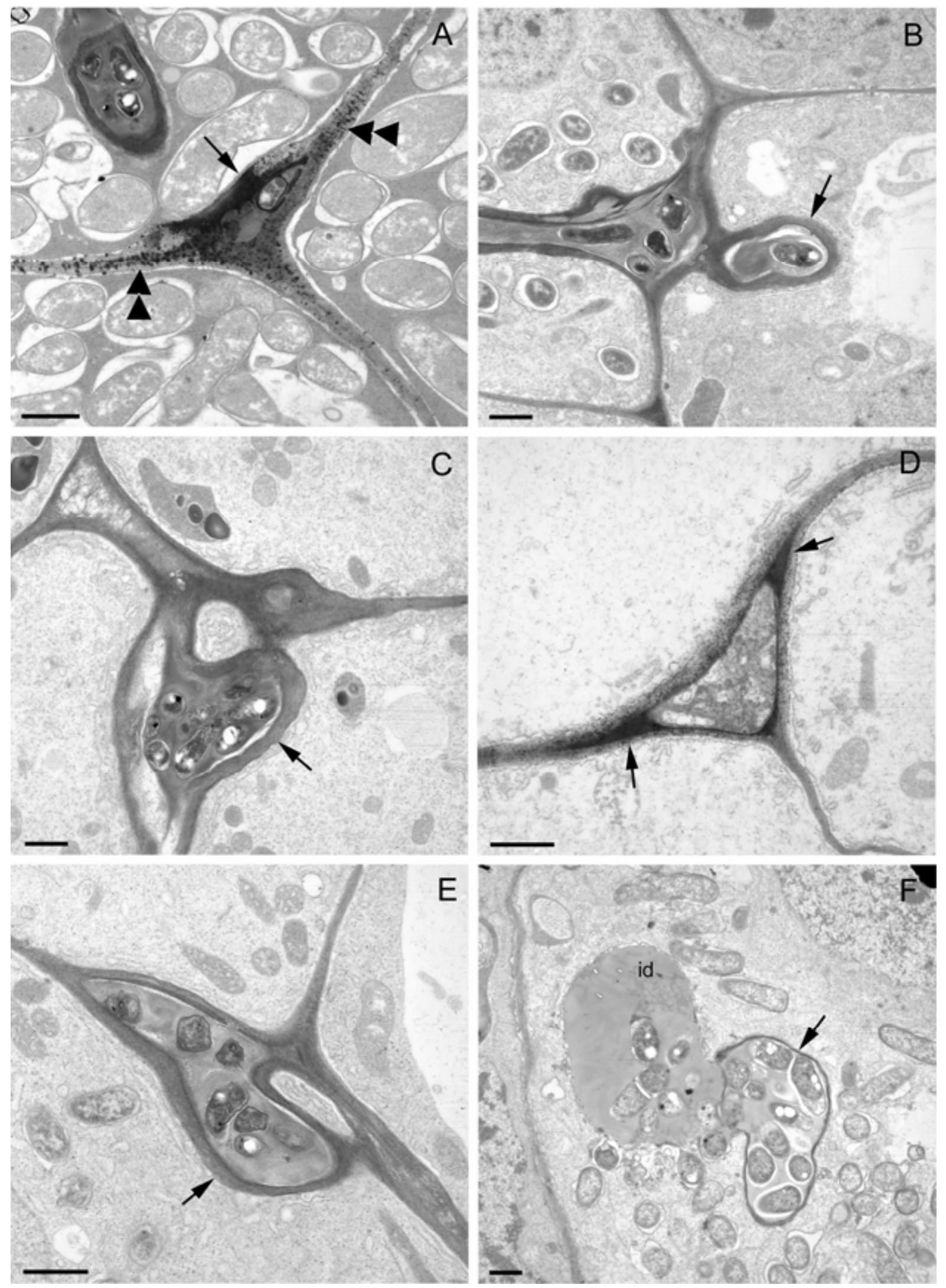

Fig. 6. Effect of inhibitors on cytochemical staining of $\mathrm{H}_{2} \mathrm{O}_{2}$ in $\mathbf{A}$ through $\mathbf{E}$, alfalfa and $\mathbf{F}$, pea nodules. A, Nodules directly perfused with cerium, without preincubation in buffer (positive control). The presence of $\mathrm{H}_{2} \mathrm{O}_{2}$ is marked by electron dense precipitates of cerium perhydroxides in the walls of the intercellular infection thread in A (arrow) as well as in the cell walls conjoining it (double arrowheads). B through E, Nodules were preincubated with $3 \mathrm{mM}$ potassium cyanide (B), $10 \mu \mathrm{M}$ diphenyleneiodonium chloride (C, D), $5 \mathrm{mM}$ sodium diethyldithiocarbamate (E), or $25 \mu \mathrm{g}$ of catalase per ml (F). No electron-dense deposits were found associated with infection threads from nodules preincubated with cyanide or dipheneyleneiodonium (arrows in B and C), although some deposits (double arrowheads) were still present in the corners of some of the cortical intercellular spaces in treated nodules (D). Similarly, no cerium deposits were visible within infection threads (arrows) or infection droplets (id) of nodules preincubated with diethyldithiocarbamate (E) or catalase (F). Bars $=1 \mu \mathrm{m}$. 
tinguish between the two mechanisms and to identify the enzymatic source of $\mathrm{H}_{2} \mathrm{O}_{2}$ (Auh and Murphy 1995; Blokhina et al. 2001; Desikan et al. 1996). Although none of the inhibitors is absolutely specific (Desikan et al. 1996; Ros Barceló 1998), they provide important information as to the mechanism of $\mathrm{H}_{2} \mathrm{O}_{2}$ generation and so have been used to complement our cytochemical localization studies in nodules. Cyanide or azide (inhibitors of $\mathrm{CuZnSOD}$ and peroxidases) completely prevented $\mathrm{H}_{2} \mathrm{O}_{2}$ staining in the infection threads, cell walls, and apoplast. Likewise, DPI (inhibitor of neutrophil NADPH oxidase) (Desikan et al. 1996) and DDC (inhibitor of CuZnSOD) (Heikkila et al. 1976) prevented $\mathrm{H}_{2} \mathrm{O}_{2}$ accumulation in infection threads and largely reduced $\mathrm{H}_{2} \mathrm{O}_{2}$ in the cell walls and apoplast. Because DPI does not inhibit SODs or peroxidases (Auh and Murphy 1995) and cyanide does not inhibit NADPH oxidase (Lamb and Dixon 1997), our results are consistent with the sequential operation of a neutrophil-like NADPH oxidase and a cyanide-sensitive enzyme to produce $\mathrm{H}_{2} \mathrm{O}_{2}$. The inhibition by DDC of $\mathrm{H}_{2} \mathrm{O}_{2}$ staining in the infection threads points to $\mathrm{CuZnSOD}$ as the cyanide-sensitive enzyme. Interestingly, using a similar antibody to localize 'cytosolic' CuZnSOD and an in vivo staining for superoxide radicals, Ogawa and associates (1996) concluded that apoplastic CuZnSOD provides the $\mathrm{H}_{2} \mathrm{O}_{2}$ required for lignification in spinach leaves and hypocotyls. In contrast, Ros Barceló (1998) attributed the generation of $\mathrm{H}_{2} \mathrm{O}_{2}$ required for lignification in the xylem of Zinnia elegans to a coupling of NADPH oxidase and peroxidases. Based on the inhibition studies and on the colocalization of $\mathrm{CuZnSOD}$ and $\mathrm{H}_{2} \mathrm{O}_{2}$ at critical sites for nodule formation, we propose that at least some of the $\mathrm{H}_{2} \mathrm{O}_{2}$, especially that in the infection threads, is generated by CuZnSOD. Nevertheless, DDC caused only a partial inhibition of $\mathrm{H}_{2} \mathrm{O}_{2}$ staining in the cell walls and apoplast, whereas azide, which is a poor inhibitor of $\mathrm{CuZnSOD}$ (Misra and Fridovich 1978) but a strong inhibitor of peroxidases, completely prevented $\mathrm{H}_{2} \mathrm{O}_{2}$ accumulation. This supports the participation of an additional enzyme, probably a cell wall peroxidase inhibitable by cyanide and azide, in the production of apoplastic and cell wall $\mathrm{H}_{2} \mathrm{O}_{2}$. Whether $\mathrm{CuZnSOD}$ may provide $\mathrm{H}_{2} \mathrm{O}_{2}$ to this cell wall peroxidase in a similar way as that proposed for lignification (Ogawa et al. 1996) requires further investigation.

Two other potential sources of $\mathrm{H}_{2} \mathrm{O}_{2}$ in the intercellular spaces of nodules should be considered. Diamine oxidase is a $\mathrm{Cu}$-containing enzyme abundant in the apoplast of legume tissues, including nodules, where it may play a role in cell wall strengthening (Laurenzi et al. 2001) and in polymerization of extensin-like glycoproteins (Wisniewski et al. 2000). This enzyme may be inhibited by the $\mathrm{Cu}$-chelator DDC (Medda et al. 1995), but it is unclear if cyanide has any effect on the activity. There are also reports of an apoplastic germin-like protein that exhibits MnSOD activity (Yamahara et al. 1999) and is involved in pathogen resistance in cereals (Christensen et al. 2004). However, this SOD activity is insensitive to cyanide (Yamahara et al. 1999) and, hence, probably not responsible for significant $\mathrm{H}_{2} \mathrm{O}_{2}$ generation in our nodule preparations.

A final novel observation in this work is that $\mathrm{H}_{2} \mathrm{O}_{2}$ accumulates surrounding the bacteroids in zone IV of indeterminate nodules. In this nodule region, bacteroids have lost their structural integrity and there is a large decrease in antioxidant defenses, oxidative degradation of leghemoglobin to nonfunctional green pigments, and enhanced autolytic processes (Matamoros et al. 1999; Mellor 1989). Hence, the $\mathrm{H}_{2} \mathrm{O}_{2}$ found in zone IV is probably associated with the oxidative stress ensued during nodule senescence. Alesandrini and associates (2003) found that $\mathrm{H}_{2} \mathrm{O}_{2}$ accumulates in the infected region of senescing soybean nodules and proposed that the periphery of the infected region is undergoing programmed cell death. A similar process could be occurring in zone IV of indeterminate nodules.

\section{MATERIALS AND METHODS}

\section{Biological material.}

Plants were inoculated and grown in pots containing perlite and vermiculite in controlled-environment cabinets, as indicated previously (Matamoros et al. 1999). Plant age at harvest was 56 days for alfalfa (Medicago sativa L. cv. Aragón $\times$ Sinorhizobium meliloti 102F78) and 30 to 35 days for pea (Pisum sativum $\mathrm{L}$. cv. Lincoln $\times$ Rhizobium leguminosarum bv. viciae NLV8). Nodules to be used for determination of isozyme composition were stored at $-80^{\circ} \mathrm{C}$, whereas those to be used for microscopy were processed immediately after harvest.

Isolation of bacteria, bacteroids, and nodule plant fraction.

Bacteria were grown at $28^{\circ} \mathrm{C}$ in yeast extract-mannitol medium ( $\mathrm{pH}$ 6.8), were harvested by centrifugation, were washed in buffer, and were disrupted in an ice-melting bath by sonication (Becana et al. 1989). Bacteroids were purified from fresh nodules using self-generating Percoll gradients, according to described methods (Reibach et al. 1981). The nodule plant fraction was extracted in optimized SOD medium as described (Rubio et al. 2002).

Activity, isozyme composition, and molecular mass of SODs.

The extraction of SOD from nodules and its assay by the ferric cytochrome $c$ method were done in optimized media, as described in detail earlier (Rubio et al. 2002). In our conditions, dialysis of extracts prior to the SOD assays was found not to be necessary, as controls consisting of boiled extracts had $<4 \%$ residual SOD activity. The SOD isozymic pattern was determined by activity staining in $15 \%$ acrylamide native gels. The in-gel activity stain was based on the inhibition by SOD of the reduction of nitroblue tetrazolium by the superoxide radicals generated photochemically. Identification of isozymes was based on the differential inhibition of SOD activity on gels preincubated with $3 \mathrm{mM} \mathrm{KCN}$ or $5 \mathrm{mM} \mathrm{H} \mathrm{H}_{2}$ for $1 \mathrm{~h}$ (Beauchamp and Fridovich 1971). The apparent molecular mass of SOD isozymes was estimated with Ferguson's plots as described by Hedrick and Smith (1968), except that slab minigels were used instead of disk gels.

\section{In situ RNA hybridization.}

Processing and in situ hybridization of nodule sections were carried out according to Trepp and associates (1999). The probes for the cytosolic CuZnSOD and mitochondrial MnSOD transcripts were prepared from a pea nodule cDNA library, using specific primers (5'-CATTGAACAATGGTGAAGGCT GTG-3' and 5'-CAACAGCACGCACAGTGGAGAG-3' for sodCc; 5'-GGATCTCGCTTACGACTACGGAG-3' and 5'-GG CATGTTCCCAAACATCTATCC-3' for $\operatorname{sodA}$ ) based on homologous sequences (accession numbers M63003 and $\mathrm{X} 60170$, respectively). The probe for $\operatorname{sod} C \mathrm{c}$ showed no significant sequence homology, except for two small stretches, with the plastid $\mathrm{CuZnSOD}$ gene $(\operatorname{sod} C p)$. In alfalfa and probably also in pea nodules, the transcript level of $\operatorname{sod} C p$ is only $5 \%$ of that of $s o d C c$, as estimated by real-time polymerase chain reaction (J. Ramos and M. Becana, unpublished data), and the hybridization of nodule sections with a specific sodCp probe did not produce signal. Thus, the $\operatorname{sod} C \mathrm{C}$ probe did not detect sodCp expression. The sodA genes encoding mitochondrial and bacteroid MnSODs have no significant homology. The alfalfa leghemoglobin cDNA (MsLb3, accession number M91077) was a gift from A. Hirsch (University of California, Los Angeles). 


\section{Immunoblot analysis.}

Total proteins were extracted from nodules in SOD extraction buffer, were resolved in $12.5 \%$ acrylamide SDS gels, and were blotted onto polyvinylidene fluoride membranes (Pall Corporation-Gelman, Ann Arbor, MI, U.S.A.). Immunoblot analysis was carried out following standard protocols, using a dilution of $1: 3,000$ to $1: 5,000$ of rabbit polyclonal antibodies raised against cytosolic $\mathrm{CuZnSOD}$ and plastid CuZnSOD from spinach (Kanematsu and Asada 1990) and against mitochondrial MnSOD from rice (Kanazawa et al. 2000). The secondary antibody was goat anti-rabbit immunoglobulin $\mathrm{G}$ horseradish peroxidase conjugate (Sigma) at a dilution of 1:20,000. Immunoreactive proteins were visualized using a highly sensitive chemiluminescent substrate for peroxidase detection (SuperSignal West Pico, Pierce, Rockford, IL, U.S.A.).

\section{Immunogold localization.}

Fresh alfalfa and pea nodules were immediately fixed in $2.5 \%$ glutaraldehyde in $0.1 \mathrm{M}$ sodium cacodylate. Slices (200 $\mu \mathrm{m})$ of five nodules from each species were taken using a Vibratome 1000 (Agar Scientific, Stansted, U.K.) and were immersed overnight in $1.8 \mathrm{M}$ sucrose before being rapidly frozen in liquid $\mathrm{N}_{2}$. The frozen samples were then freeze-substituted in methanol containing $0.5 \%$ uranyl acetate (Sigma) at $-90^{\circ} \mathrm{C}$, $-65^{\circ} \mathrm{C}$, and $-45^{\circ} \mathrm{C}$ over a period of $68.5 \mathrm{~h}$, and finally, were embedded in Lowicryl HM23 resin (Polysciences, Warrington, PA, U.S.A.) at $-45^{\circ} \mathrm{C}$ under UV light using a EM AFS freezesubstitution unit (Leica, Vienna, Austria). Ultrathin sections were taken on a Leica Ultracut E microtome, were collected on nickel grids coated in pioloform and carbon, and were immunogold labeled, using the anti-SOD polyclonal antibodies indicated above, according to James and associates (1996). Sections were first incubated for $1 \mathrm{~h}$ on a blocking/diluting buffer containing $1 \%$ Tween $20,1 \%$ bovine serum albumin, and $1 \%$ normal goat serum (Sigma) in Tris-buffered saline containing $0.5 \mathrm{~g}$ of polyethylene glycol- $20 \mathrm{~K}$ and $14 \mathrm{mM}$ sodium azide per liter, then for $2 \mathrm{~h}$ in a 1:500 dilution (in buffer) of the primary antibody. After washing, the grids were incubated in a 1:50 dilution of goat anti-rabbit antibodies conjugated to 15nm gold particles (Amersham Biosciences, Little Chalfont, U.K.) for $1 \mathrm{~h}$. As controls, serial sections were immunogold labeled with nonimmune serum (diluted 1:500) substituted for the primary antibodies. The immunogold labeled sections were stained with $2 \%$ aqueous uranyl acetate for $10 \mathrm{~min}$ before being viewed and photographed under a JEOL 1200 EX transmission electron microscope.

\section{Hydrogen peroxide localization.}

Fresh nodules were quickly cut into small pieces $(<1 \mathrm{~mm})$ and were immediately perfused in $10 \mathrm{mM}$ cerium chloride (Sigma) in $50 \mathrm{mM} 3$-morpholinopropanesulfonic acid (MOPS) $(\mathrm{pH} 7.0)$ for $1 \mathrm{~h}$ prior to fixation in $2.5 \%$ glutaraldehyde in 0.1 $\mathrm{M}$ sodium cacodylate. Nodules with and without cerium chloride (negative control) were postfixed for $1 \mathrm{~h}$ in $1 \%$ osmium tetroxide in $0.1 \mathrm{M}$ sodium cacodylate, were dehydrated in an ethanol series at room temperature, and finally, were embedded in Agar 100 epoxy resin (Agar Aids, Stansted, U.K.) at $55^{\circ} \mathrm{C}$. Ultrathin sections were stained with lead citrate for 5 min, followed by $2 \%$ aqueous uranyl acetate for $10 \mathrm{~min}$, and $\mathrm{H}_{2} \mathrm{O}_{2}$ was localized as electron-dense precipitates of cerium perhydroxides (Bestwick et al. 1997).

\section{Inhibitor studies.}

Fresh nodules were cut as indicated above and preincubated for $30 \mathrm{~min}$ in $50 \mathrm{mM}$ MOPS (pH 7.0) alone (control) or supplemented with catalase or enzyme inhibitors (all from Sigma) at the following concentrations (per ml): $25 \mu \mathrm{g}$ of catalase per $\mathrm{ml}, 3 \mathrm{mM}$ potassium cyanide, $1 \mathrm{mM}$ sodium azide, $10 \mu \mathrm{M}$ DPI, or $5 \mathrm{mM}$ DDC. Solutions were then replaced by $5 \mathrm{mM}$ cerium chloride in $50 \mathrm{mM}$ MOPS ( $\mathrm{pH} 7.0$ ), containing or not containing the inhibitors. Nodule samples were further incubated for $1 \mathrm{~h}$ and were fixed and processed as described above. Additional controls, in which the 30-min preincubation period was omitted, were run in parallel.

\section{ACKNOWLEDGMENTS}

We thank S. Kanematsu and T. Ushimaru for their generous gifts of the CuZnSOD and MnSOD antibodies, C. Bestwick for helpful insights on the cerium perfusion technique, and A. Hirsch for kindly providing the leghemoglobin probe. Thanks are also due to M. Kierans for technical assistance on electron microscopy and to two anonymous reviewers for valuable comments on the manuscript. This work was supported by grant AGL2002-02876 from the Dirección General de Investigación, Ministry of Science and Technology (Spain).

\section{LITERATURE CITED}

Alesandrini, F., Mathis, R., Van de Sype, G., Hérouart, D., and Puppo, A. 2003. Possible roles for a cysteine protease and hydrogen peroxide in soybean nodule development and senescence. New Phytol. 158:131138.

Auh, C.-K., and Murphy, T. M. 1995. Plasma membrane redox enzyme is involved in the synthesis of $\mathrm{O}_{2}^{-}$and $\mathrm{H}_{2} \mathrm{O}_{2}$ by Phytophthora elicitorstimulated rose cells. Plant Physiol. 107:1241-1247.

Beauchamp, C., and Fridovich, I. 1971. Superoxide dismutase: Improved assays and an assay applicable to acrylamide gels. Anal. Biochem. 44:276-287.

Becana, M., Paris, F. J., Sandalio, L. M., and del Río, L. A. 1989. Isoenzymes of superoxide dismutase in nodules of Phaseolus vulgaris L. Pisum sativum L., and Vigna unguiculata (L.) Walp. Plant Physiol. 90:1286-1292.

Bestwick, C. S., Brown, I. R., Bennett, M. R., and Mansfield, J. W. 1997. Localization of hydrogen peroxide accumulation during the hypersensitive reaction of lettuce cells to Pseudomonas syringae pv. phaseolicola. Plant Cell 9:209-221.

Blokhina, O. B., Chirkova, T. V., and Fagerstedt, K. V. 2001. Anoxic stress leads to hydrogen peroxide formation in plant cells. J. Exp. Bot. 52:1179-1190.

Bueno, P., Soto, M. J., Rodríguez-Rosales, M. P., Sanjuan, J., Olivares, J., and Donaire, J. P. 2001. Time-course of lipoxygenase, antioxidant enzyme activities and $\mathrm{H}_{2} \mathrm{O}_{2}$ accumulation during the early stages of Rhizobium-legume symbiosis. New Phytol. 152:91-96.

Christensen, A. B., Thordal-Christensen, H., Zimmermann, G., Gjetting, T., Lyngkjaer, M. F., Dudler, R., and Schweizer, P. 2004. The germinlike protein GLP4 exhibits superoxide dismutase activity and is an important component of quantitative resistance in wheat and barley. Mol. Plant-Microbe Interact. 17:109-117.

Corpas, F. J., Sandalio, L. M., Palma, J. M., Leidi, E. O., Hernández, J. A., Sevilla, F., and del Río, L. A. 1991. Subcellular distribution of superoxide dismutase in leaves of ureide-producing leguminous plants. Physiol. Plant. 82:285-291.

Dalton, D. A. 1995. Antioxidant defenses of plants and fungi. Pages 298355 in: Oxidative Stress and Antioxidant Defenses in Biology. S. Ahmad, ed. Chapman and Hall, New York.

Desikan, R., Hancock, J. T., Coffey, M. J., and Neill, S. J. 1996. Generation of active oxygen in elicited cells of Arabidopsis thaliana is mediated by a NADPH oxidase-like enzyme. FEBS (Fed. Eur. Biochem. Soc.) Lett. 382:213-217.

D'Haeze, W., De Rycke, R., Mathis, R., Goormachtig, S., Pagnotta, S., Verplancke, C., Capoen, W., and Holsters, M. 2003. Reactive oxygen species and ethylene play a positive role in lateral root base nodulation of a semiaquatic legume. Proc. Natl. Acad. Sci. U.S.A. 100:11789-11794.

Escuredo, P. R., Minchin, F. R., Gogorcena, Y., Iturbe-Ormaetxe, I., Klucas, R. V., and Becana, M. 1996. Involvement of activated oxygen in nitrateinduced senescence of pea root nodules. Plant Physiol. 110:1187-1195.

Evans, P. J., Gallesi, D., Mathieu, C., Hernandez, M. J., de Felipe, M. R., Halliwell, B., and Puppo, A. 1999. Oxidative stress occurs during soybean nodule senescence. Planta 208:73-79.

Fridovich, I. 1989. Superoxide dismutases. An adaptation to a paramagnetic gas. J. Biol. Chem. 264:7761-7764

Grant, J. J., and Loake, G. J. 2000. Role of reactive oxygen intermediates and cognate redox signaling in disease resistance. Plant Physiol. 124:21-29. 
Hedrick, J. L., and Smith, A. J. 1968. Size and charge isomer separation and estimation of molecular weights of proteins by disc gel electrophoresis. Arch. Biochem. Biophys. 126:155-164.

Heikkila, R. E., Cabbat, F. S., and Cohen, G. 1976. In vivo inhibition of superoxide dismutase in mice by diethyldithiocarbamate. J. Biol. Chem. 251:2182-2185.

Hérouart, D., Van Montagu, M., and Inzé, D. 1993. Redox-activated expression of the cytosolic copper/zinc superoxide dismutase gene in Nicotiana. Proc. Natl. Acad. Sci. U.S.A. 90:3108-3112.

James, E. K., Iannetta, P. P. M., Nixon, P. J., Whiston, A. J., Peat, L., Crawford, R. M. M., Sprent, J. I., and Brewin, N. J. 1996. Photosystem II and oxygen regulation in Sesbania rostrata stem nodules. Plant Cell Environ. 19:895-910.

Kanazawa, S., Sano, S., Koshiba, T., and Ushimaru, T. 2000. Changes in antioxidative enzymes in cucumber cotyledons during natural senescence: Comparison with those during dark-induced senescence. Physiol. Plant 109:211-216.

Kanematsu, S., and Asada, K. 1990. Characteristic amino acid sequences of chloroplast and cytosol isozymes of $\mathrm{CuZn}$-superoxide dismutase in spinach, rice and horsetail. Plant Cell Physiol. 31:99-112.

Lamb, C., and Dixon, R. A. 1997. The oxidative burst in plant disease resistance. Annu. Rev. Plant Physiol. Plant Mol. Biol. 48:251-275.

Laurenzi, M., Tipping, A. J., Marcus, S. E., Knox, J. P., Federico R. Angelini, R., and McPherson, M. J. 2001. Analysis of the distribution of copper amine oxidase in cell walls of legume seedlings. Planta 214:37-45

Levine, A., Tenhaken, R., Dixon, R., and Lamb, C. 1994. $\mathrm{H}_{2} \mathrm{O}_{2}$ from the oxidative burst orchestrates the plant hypersensitive disease resistance response. Cell 79:583-593.

Martínez-Abarca, F., Herrera-Cervera, J. A., Bueno, P., Sanjuan, J., Bisseling, T., and Olivares, J. 1998. Involvement of salicylic acid in the establishment of the Rhizobium meliloti-alfalfa symbiosis. Mol. PlantMicrobe Interact. 11:153-155.

Matamoros, M. A., Moran, J. F., Iturbe-Ormaetxe, I., Rubio, M. C., and Becana, M. 1999. Glutathione and homoglutathione synthesis in legume root nodules. Plant Physiol. 121:879-888.

Medda, R., Padiglia, A., and Floris, G. 1995. Plant copper-amine oxidases. Phytochemistry 39:1-9.

Mellor, R. B. 1989. Bacteroids in the Rhizobium-legume symbiosis inhabit a plant internal lytic compartment: Implications for other microbial endosymbioses. J. Exp. Bot. 40:831-839.

Misra, H. P., and Fridovich, I. 1978. Inhibition of superoxide dismutases by azide. Arch. Biochem. Biophys. 189:317-322.

Ogawa, K., Kanematsu, S., and Asada, K. 1996. Intra- and extra-cellular localization of "cytosolic" CuZn-superoxide dismutase in spinach leaf and hypocotyl. Plant Cell Physiol. 37:790-799.

Puppo, A., Dimitrijevic, L., and Rigaud, J. 1987. $\mathrm{O}_{2}$ consumption and superoxide dismutase content in purified mitochondria from soybean root nodules. Plant Sci. 50:3-11.

Ramu, S. K., Peng, H.-M., and Cook, D. R. 2002. Nod factor induction of reactive oxygen species production is correlated with expression of the early nodulin gene ripl in Medicago truncatula. Mol. Plant-Microbe Interact. 15:522-528.

Reibach, P. H., Mask, P. L., and Streeter, J. G. 1981. A rapid one-step method for the isolation of bacteroids from root nodules of soybean plants, utilizing self-generating Percoll gradients. Can. J. Microbiol. 27:491-495.

Ros Barceló, A. 1998. The generation of $\mathrm{H}_{2} \mathrm{O}_{2}$ in the xylem of Zinnia elegans is mediated by an NADPH-oxidase-like enzyme. Planta 207:207216.

Rubio, M. C., González, E. M., Minchin, F. R., Webb, K. J., Arrese-Igor C., Ramos, J., and Becana, M. 2002. Effects of water stress on antioxidant enzymes of leaves and nodules of transgenic alfalfa overexpressing superoxide dismutases. Physiol. Plant. 115:531-540.

Salzwedel, J. L., and Dazzo, F. B. 1993. pSym nod gene influence on elicitation of peroxidase activity from white clover and pea roots by rhizobia and their cell-free supernatants. Mol. Plant-Microbe Interact. 6:127-134.

Santos, R., Hérouart, D., Sigaud, S., Touati, D., and Puppo, A. 2001. Oxidative burst in alfalfa-Sinorhizobium meliloti symbiotic interaction. Mol. Plant-Microbe Interact. 14:86-89.

Scandalios, J. G. 1997. Molecular genetics of superoxide dismutases in plants. Pages 527-568 in: Oxidative Stress and the Molecular Biology of Antioxidant Defenses. J. G. Scandalios, ed. Cold Spring Harbor Laboratory Press, Cold Spring Harbor, NY, U.S.A

Shaw, S. L., and Long, S. R. 2003. Nod factor inhibition of reactive oxygen efflux in a host legume. Plant Physiol. 132:2196-2204.

Trepp, G. B., Temple, S. J., Bucciarelli, B., Shi, L. F., and Vance, C. P. 1999 Expression map for genes involved in nitrogen and carbon metabolism in alfalfa root nodules. Mol. Plant-Microbe Interact. 12:526-535.

Vasse, J., de Billy, F., Camut, S., and Truchet, G. 1990. Correlation between ultrastructural differentiation of bacteroids and nitrogen fixation in alfalfa nodules. J. Bacteriol. 172:4295-4306.

Vasse, J., de Billy, F., and Truchet, G. 1993. Abortion of infection during the Rhizobium meliloti-alfalfa symbiotic interactions is accompanied by a hypersensitive reaction. Plant J. 4:555-566.

Wisniewski, J. P., Rathbun, E. A., Knox, J. P., and Brewin, N. J. 2000. Involvement of diamine oxidase and peroxidase in insolubilization of the extracellular matrix: Implications for pea nodule initiation by Rhizobium leguminosarum. Mol. Plant-Microbe Interact. 13:413-420.

Yamahara, T., Shiono, T., Suzuki, T., Tanaka, K., Takio, S., Sato, K. Yamazaki, S., and Satoh, T. 1999. Isolation of a germin-like protein with manganese superoxide dismutase activity from cells of a moss, Barbula unguiculata. J. Biol. Chem. 274:33274-33278. 